\title{
Constraints Experienced by Tribal Farmers in the Information Management
}

\author{
K. Naresh* and R.D. Ahire \\ Department of Extension Education, Vasantrao Naik Marathwada Krishi Vidyapeeth, \\ Parbhani-431 402 (M.S.), India \\ *Corresponding author
}

\section{A B S T R A C T}

\begin{tabular}{|l|}
\hline Ke y w o r d s \\
Constraints, \\
Knowledge and \\
Technology
\end{tabular}

Total of 120 respondents were selected as sample respondents for this study. The present study was conducted purposively in selected Kinwat and Mahur tahsil of Nanded district as Kinwat taluka having highest tribal population in Marathwada region. Data were collected through personal interview schedule. Results on the information management behavior of tribal farmers revealed that majority of respondents on Information Management Behaviour (82.50\%) were grouped under medium category followed by low $(10.83 \%)$ and high $(06.66 \%)$ categories and information acquisition behaviour indicates that majority of respondents grouped under medium category $(80.00 \%)$ followed by low $(15.83 \%)$ category. The major constraints identified by The tribal farmers in information management behaviour indicates that 'lack of knowledge on various information evaluation methods', was emerged as the major constraint followed by 'lack of sufficient tours and field trips for the farmers', ' lack of time and mobility to meet scientists and extensionists', 'lack of sufficient training programmes'.

\section{Introduction}

Now days, information is a basic necessity of everyday life. For anything and everything information is required. Information can be obtained or retrieved from a variety of sources. Farmers constitute a particular group of users whose information needs is very specific. The present paper deals with the information needs of the farmer community in rural areas. Agricultural Information System (AIS) is a system in which agricultural information is generated, consolidated, received and feed back in such a manner that these processes function synergistically to understand knowledge utilization by agricultural producers (Rolling, 1988). The present paper deals with the information needs of the farmer community in rural areas. The study conducted through survey method and reveals that $(40.58 \%)$ farmers require daily information for various agriculture works. Maharashtra state comprises 35 districts which are grouped into six divisions for administrative purpose. As per the 2011 census, Maharashtra has a population of $112,372,972$ registering a population density of 365 per sq. kms. Out of the total population males constitute 58.3millions and females constitute 54.0 millions. The population in 
Nanded district is 33, 61,292 as per census 2011 of which tribal population is $2,81,695$ respectively. Therefore, there is a need to know the behaviour of farmers on management of agricultural related information. Hitherto no such attempt was made in this direction. However it is observed that 'lack of sufficient tours and field trips for the farmers', ' lack of time and mobility to meet scientists and extensionists', 'lack of sufficient training programmes' Therefore, study was conducted to identify the constraints faced by tribal farmers in the information management.

\section{Materials and Methods}

The present study conducted during 2015-16 year in Marathwada region as considerable are under where maximum tribal population. In Marathwada region one district namely Nanded are selected purposively for the study. From these districts ten villages selected that is five villages from each tahsil were selected purposively for study. From Mahur tahsil two tahsil selected that is ten villages were selected purposively from Kinwat and Mahur tahsil Mahur, Kupti, Vanula, Pachunda, Sakhur and from Kinwat tahsil Gokunda, Bodhadi, Chikhali, Mohapur, Malborgaon were selected as considerable area under maximum population of tribal people from each village twelve respondents were select randomly from each village to comprise the sample of 120 respondents for study. The data from the respondents were collected through personal interview schedule. The collected data was analyzed with the help of suitable statistical methods i.e. percentage, frequency and mean.

\section{Results and Discussion}

Information management behaviour has been depicted in Table 1 and relevant discussions have been summarized under following heads:

\section{Information acquisition behaviour}

The distribution of respondents on information acquisition behaviour indicates that majority of respondents grouped under medium category $(80.00 \%)$ followed by low $(15.83 \%)$ category.

This finding is inline with the results of Amtulwaris (2004).

\section{Information processing behaviour}

The distribution of respondents on information processing behaviour indicates that majority of them grouped under medium category $(82.50 \%)$.

Followed by low category $(10.00 \%)$ this indicates that the farmers are not well aware on various techniques of information processing like information evaluation treatment and storage.

These results are in conformity with the findings of Ravindra et al., (2009).

\section{Information dissemination behaviour}

The distribution of respondents on information dissemination behaviour shows that majority of respondents $(80.00 \%)$ were grouped under medium category followed by low $(11.66 \%)$.

The lack of understanding on power of various tools and techniques / methods in sharing the information with other farmers could be the reason for falling under medium followed by low categories.

This finding is inline with the results of Shanmuga and kangasabapathi (2008).

The constraints identified by the farmers in their Information Management Behaviour are shown in the Table 2. 
Table.1 Information management behavior of tribal farmers

\begin{tabular}{|c|c|c|c|}
\hline Sr.No. & Category & Frequency & Percentage \\
\hline 1 & Low & 19 & 15.83 \\
\hline 2 & Medium & 96 & 80.10 \\
\hline 3 & High & 5 & 04.17 \\
\hline \multicolumn{4}{|c|}{ 2.Distribution of respondents with regard to their information processing behaviour } \\
\hline Sr.No. & Category & Frequency & Per cent \\
\hline 1 & Low & 12 & 10.00 \\
\hline 2 & Medium & 99 & 82.50 \\
\hline 3 & High & 9 & 07.50 \\
\hline \multicolumn{4}{|c|}{ 3.Distribution of respondents with regard to their information dissemination behaviour } \\
\hline Sr.No. & Category & Frequency & Per cent \\
\hline 1 & Low & 14 & 11.66 \\
\hline 2 & Medium & 96 & 80.00 \\
\hline 3 & High & 10 & 08.34 \\
\hline \multicolumn{4}{|c|}{ 4. Distribution of respondents with regard to their information management behaviour } \\
\hline Sr.No. & Category & Frequency & Per cent \\
\hline 1 & Low & 13 & 10.83 \\
\hline 2 & Medium & 99 & 82.50 \\
\hline \multirow[t]{2}{*}{3} & High & 8 & 06.66 \\
\hline & Total & 120 & 100.00 \\
\hline
\end{tabular}

Table.2 Constraints faced by tribal farmers in their information management behaviour

\begin{tabular}{|c|c|c|c|c|}
\hline \multirow[t]{2}{*}{ Sr. No } & \multirow[t]{2}{*}{ Constraints } & \multicolumn{3}{|c|}{ Respondents } \\
\hline & & Frequency & Percentage & Rank \\
\hline 1 & $\begin{array}{l}\text { Limited contacts with the officials of development } \\
\text { departments scientists/extensionists }\end{array}$ & 36 & 30.00 & $\overline{X I}$ \\
\hline 2 & $\begin{array}{l}\text { Lack of adequate time to read newspapers/listen } \\
\text { radio/view TV programmes }\end{array}$ & 28 & 23.33 & XIV \\
\hline 3 & $\begin{array}{l}\text { Lack of opportunity to participate in different } \\
\text { extension activities }\end{array}$ & 41 & 34.16 & IX \\
\hline 4 & $\begin{array}{l}\text { Lack of opportunities to participate in farm } \\
\text { broadcasts/farm telecasts }\end{array}$ & 42 & 35.00 & III \\
\hline$\overline{5}$ & $\begin{array}{l}\text { Lack of time and mobility to meet scientists and } \\
\text { extensionists }\end{array}$ & 32 & 51.66 & III \\
\hline 6 & Low literacy levels & 25 & 26.66 & XIII \\
\hline 7 & Lack of sufficient training programmes & 58 & 48.33 & IV \\
\hline 8 & $\begin{array}{l}\text { Lack of sufficient tours and field trips for } \\
\text { the farmers }\end{array}$ & 64 & 53.33 & II \\
\hline 9 & $\begin{array}{l}\text { Lack of knowledge on various information evaluation } \\
\text { methods }\end{array}$ & 70 & 58.33 & $\mathbf{I}$ \\
\hline 10 & $\begin{array}{l}\text { Extension staff are not accessible to the farmers for } \\
\text { treatment of the messages. }\end{array}$ & 44 & 36.66 & $\begin{array}{l}\text { VII } \\
\end{array}$ \\
\hline 11 & $\begin{array}{l}\text { Lack of knowledge on importance and methods of } \\
\text { information storage }\end{array}$ & 46 & 38.33 & VI \\
\hline 12 & $\begin{array}{l}\text { No films/slide shows on agricultural aspects were } \\
\text { shown in the villages }\end{array}$ & 38 & 31.66 & $\mathbf{X}$ \\
\hline$\overline{13}$ & $\begin{array}{l}\text { Lack of knowledge on methods for sharing the } \\
\text { agricultural information with others }\end{array}$ & 35 & 29.16 & XII \\
\hline 14 & Prevalence of tenancy & 24 & 20 & $\mathbf{X V}$ \\
\hline 15 & Lack of suitable technology & 52 & 43.33 & $\mathbf{V}$ \\
\hline
\end{tabular}


It is evident from the Table 2 that majority of the respondents $(58.33 \%)$ had expressed the constraint like lack of knowledge on various information evaluation methods, lack of sufficient tours and field trips for the farmers (53.33\%), lack of time and mobility to meet scientists and extensionists (51.66\%), lack of sufficient training programmes $(48.33 \%)$, lack of suitable technology (43.33\%), lack of knowledge on importance and methods of information storage (38.33\%), extension staff are not accessible to the farmers for treatment of the messages (36.66\%), lack of opportunities to participate in farm broadcasts/farm telecasts $(35.00 \%)$, lack of opportunity to participate in different extension activities (34.16\%), no films/slide shows on agricultural aspects were shown in the villages $(31.66 \%)$, limited contacts with the officials of development departments scientists/extensionists $(30.00 \%)$, lack of knowledge on methods for sharing the agricultural information with others $(29.16 \%)$, low literacy levels (26.66 \%), lack of adequate time to read newspapers/listen radio/view TV programmes $(23.33 \%)$ and Prevalence of tenancy $(20.00 \%)$ respectively.

Majority of respondents $(82.5 \%)$ grouped under medium category in use of Information Management Behaviour followed by low
(10.83\%) and high $(06.67 \%)$ categories. The major constraints identified by the respondents in their Information Management Behaviour are 'Lack of knowledge on various information evaluation methods (58.33\%), was emerged as the major constraint followed by Lack of sufficient tours and field trips for the farmers $(53.33 \%)$, Lack of time and mobility to meet scientists and extensionist $(51.66 \%)$, Lack of sufficient training programmes $(48.33 \%)$ etc.

\section{References}

Amtulwaris, 2004. Utilization of information sources by farm women in Arid Rajasthan Indian Journal of Extension Education 40 (1\&2): 75-77.

Ravindra. P., Gawande, Milind C, Ahire, Sandip D, Patil, 2009. Mass media utilization pattern and constrains faced by cotton growers. Journal of communication studies 27: 69-78.

Rolling, Niels, 1988. Extension Science Information systems in Agricultural Systems. Cambridge University Press: 179-212.

Shanmugaraja, P. and Kanagasabapathi, K., 2008. Communication behaviour of Tribal farmers of Pachaimalai hills. Agriculture Update 3(3/4): 313- 316.

\section{How to cite this article:}

Naresh, K. and Ahire, R.D. 2018. Constraints Experienced by Tribal Farmers in the Information Management. Int.J.Curr.Microbiol.App.Sci. 7(03): 1230-1233. doi: https://doi.org/10.20546/ijcmas.2018.703.145 